\title{
SEABASS AND SEABREAM FARMED IN THE MEDITERRANEAN: SWIMMING AGAINST THE TIDE OF MARKET ORIENTATION.
}

\section{STRUCTURED ABSTRACT}

Purpose: This paper investigates how small and medium sized aquaculture producers in the Mediterranean might move from traditional high volume output systems to become more market oriented.

Design/ methodology/approach: The quantitative methodology was devised to assess production trends and potential of seabass and seabream farmed off most of the countries bordering the Mediterranean. In addition to markets adjacent to the Mediterranean producers, those in Northern Europe are also included because of the opportunities for market expansion and product diversification.

Findings: It is concluded that greatest scope for industry gain lies in supply channel members being more market orientated to meet the dynamic and varied demands of consumers. The historic but still predominant one-size fits all philosophy and business approach to fish farming is outdated and demands radical revision to realise potential added-value of the industry. This is all the more important as consumers, pressure groups and governments become more aware of the political, economic and environmental impact of food miles and wider sustainable production issues, encouraging many international food markets to move away from an emphasis upon cheap food.

Practical Implications: The study has practical implications for EU aquaculture policy and SME development to ensure more sustainable production and to promote positive benefits in often peripheral and fragile rural economies where alternative options are commonly rare and/ or conflicting.

Originality/value: The research highlights the challenges of a sector with spatially disparate points of production and consumption coupled with a highly perishable product critically dependent upon efficient distribution whilst facing emergent environmental concerns over sustainable food production systems.

Keywords: Supply chain management, marketing orientation, aquaculture, Small and Medium sized Enterprises (SMEs)

\section{Paper type: Research Paper}




\section{INTRODUCTION}

Aquaculture plays an increasingly important role in global food production with a rate of growth greater than any other food sector (Lem, 2007). Already, almost 50\% of the world's fish for human consumption now comes from aquaculture and this will increase further as supplies from traditional capture sources decline through overfishing and ongoing failure of policies to rejuvenate world fish stocks (FAO, 2006). Amongst other regions in the world there has been a significant expansion of aquaculture in Mediterranean countries where the growth of seabass and seabream stocks has generated socio-economic benefits and EU policy measures have encouraged expansion. However, like earlier agricultural experience, production-led growth has led to declining profitability and culminated in a need for structural changes in the industry focusing on realignment of supply to market requirements (Muir \& Young, 1999).

This paper focuses on factors that help and hinder horizontal collaboration in the supply chain from fry production to product consumption and evaluates factors that might facilitate alignment between upstream capability and downstream requirements. We demonstrate potential contributions for a greater understanding of the benefits of coordinating complex international supply chains. Thus the central problem addressed in this paper is "how might the supply chain for this increasingly important, yet highly perishable, food be aligned with demand to promote delivery of sustainable and quality products sought by consumers?" The questions most pertinent to the research are:-

1. How might the SME Mediterranean aquaculture producers move from traditional high output production systems to become more market oriented?

2. How might such supply chain changes be promulgated to help secure the sector's future sustainability?

This research seeks to contribute to our understanding of the challenges facing global supply chains when production is regional and to inform policy makers and practitioners operating within the industry. The research highlights the constraints of spatially disparate points of production and consumption of an endemically perishable product, which impinge on the need for both coordinated distribution as well as an understanding of end customer needs and wants. 
The following section sets out the literature review and highlights the research problem.

\section{Market orientation and supply chain management: Two sides of the same coin}

European food sectors are being radically reshaped by globalisation, as supply chains are restructured and extended (Marsend et al 1999). At the same time, food supply chains have seen a reversal from being driven by supply to being driven by consumer demand (Bosselie et al 2003). From this perspective, supply chain management is no longer seen as the means of improving efficiency through cost and waste reduction but also recognises the importance of understanding and meeting consumer needs (Taylor 2006; Croxton et al 2001, cited in Taylor and Fearne 2006; Zokai and Hines 2007, Cox et al 2007). Indeed, Rao et al (2006, cited in Cambra-Fierro and Polo Redonda 2008) state that the aim of a supply chain should be to satisfy the final customer or the end user. Consumer demand for year round availability and specific attributes such as quality, provenance and conditions of production and supply (Marsend et al 1999; Bosselie et al 2003) are determining influences on the market. Therefore it follows that "since consumers are the focus of a chain's existence, consumer demand should be at the core of a chain's business strategy." (Canever et al 2008, p. 106)

Several studies have noted performance improvements through implementation of supply chain management (Voss et al 1997) and similarly positive relationships between market orientation and profitability have been found (Hooley et al 1990; Grunert et al 2005). Miles and Arnold (1991) defined four key components of marketing orientation: customer orientation; customer satisfaction; co-ordinated or integrated marketing and a focus on profitability. Whereas, Ellram \& Cooper (1993), defined supply chain management as, "an integrating philosophy to manage the total flow of a distribution channel from supplier to ultimate customer." There are clear similarities in the principles underpinning supply chain management and market orientation when viewed from a broad perspective, as the processes within and between firms interact and coordinate to translate information and market knowledge into servicing customer requirements (Rainbird 2004). Supply chain management 
should facilitate marketing strategy by improving efficiency, reducing costs and therefore prices and in so doing create superior customer service, customer satisfaction and customer loyalty (Flint 2004). In a study of the UK beef industry Cox et al suggest that along with "the ultimate aim of supply chain coordination and the resultant benefits of waste elimination, there has also been considerable interest in the development of downstream product development and marketing strategies." (2007, p323)

Both these concepts are mechanisms to improve competitiveness by reducing uncertainty and enhancing customer service (Ring \& van de Ven 1992; van der Vorst and Beulens 2002). Some academics refer to this as value chain management (AlMudimigh et al 2004). Supply chain management emphasises efficiency and the importance of trying to reduce cost but it is response to customer demand that should drive the chain. Fisher (1997) articulates this by highlighting two functions of the supply chain: the physical and market mediation. The physical involves raw material transformation into finished products, then transported to various parts of the supply chain; eg whole fish processed into chilled pre-packed fillets. Market mediation simply ensures "the mix of variants which is brought to the market matches what customers want to buy"; eg whether consumers want their fillets with or without skin and/ or bones. The supply chain and product market characteristics are thus closely aligned.

"Supply Chain Management is emerging into consumer driven value chain management which, in addition to pursuing efficiency improvements, recognizes the importance of consumer needs and attempts to capture subtleties of consumer value as a source of differentiation and supply chain competitiveness" (Zokaei and Hines 2007).

This is particularly important when dealing with a commodity such as fish because "entering a value-added market can help to cushion farmers against price volatility of commodity markets.” (Cox et al, 2007, p 323)

Understanding emergent customer needs demands ongoing internal information systems and multiple external connections to suppliers, processors, and customers. The challenge is getting the various pieces in the pipeline to connect and communicate (Sheridan and Leibs 1999; Rainbird 2004). In the context of the 
global supply chain, firms will hold important, possibly different, benefits and will accept varying levels of performance due to national cultures, regional business norms, economic situations and regulatory environments (Closs \& Mollenkopf 2004). Bello et al (2004) also recognise cultural mediation of trading partners' contractual, ownership and social interactions. Supplier co-ordination and supplier development are seen as central to achieve high quality and delivery performance along with the benefits of supplier collaboration (Rich \& Hines 1997). Collective action can help to improve performance for agri-food SMEs and can take many forms for example, farmer co-operatives (Lamprinopoulou et al 2006), or supplier hubs (Wagner \& Aldredice 2006).

Developing effective business relationships is difficult and even more so when suppliers are spread around the globe (Handfield 2004). Difficulties are often exacerbated where global changes driven by powerful retailers, adversely impact on producers' traditional way of life causing resistance to change. Although information systems enable suppliers and customers to communicate, buyers and sellers must also build relationships through face-to-face interaction. This enables customers' needs to be directly related to suppliers' capabilities and encourage higher conformance and benefit delivery (Handfield 2004). Closs \& Mollenkopf (2004) echo this by linking supply chain performance to operational, planning performance and marketing strategy. Firms generally understand their immediate downstream customer values very well, but this soon diminishes further along the chain. The problem has been articulated by Ottesen (2006) who states that many small upstream firms seldom have contact with consumers and do not know the final consumer's wants and needs. Yet, small firms' survival is dependent on being able to satisfy end user needs. The challenge for firms is to recognise that all channel members must understand in detail what each firm in their supply chain holds important (Closs \& Mollenkopf 2004). Clearly, sharing information, and the clarity and accuracy of that provided, will depend on how well the actors in the chain know and trust each other (Sako 2002).

Growth in the internationalisation of business and markets has led to a need for analysis of the role and the effectiveness of strategies in different markets. Some strategists have generalised: the market environment in different countries influences the types of strategies that companies develop and adopt, which in turn influences 
business performance (Sin et al 2005). Lamprinopoulou et al's (2006) study into agrifood SMEs in Greece identified a number of specific conditions which exist as facilitators or barriers to collective action: socio-economic context, such as the type of market, cohesiveness of the networks and the level of local and government support and behavioural conditions, which refer to skills and competences of the individual organisations and the degree to which they were market oriented. They promulgate market orientation as a behavioural condition necessary to facilitate collective action. This argument is reinforced by Grunert et al (2005) for whom extension of market orientation along the chain is dependent upon the extent to which members research the end users' wants and needs. Their study of four food chains,found that differences in market orientation may be determined by the degree of end user heterogeneity, the nature of chain relationships, regulations and prevailing attitudes. It has also been suggested that in industries where it is difficult for firms to differentiate on the basis of product characteristics, a strong marketing orientation is needed for growth (MacMillan \& McGrath 1997; Tzokas et al 2001).

The implications of a market orientation have long been recognised in the business-tobusiness market, distinguishable from consumer marketing by the nature of the customer rather than the product (Webster 1979:74). Business-to-business marketing stresses the importance of the external customer and the market is central to what has become identified as a marketing orientation, where networks and relationships are fundamental (Baker 1999). A marketing orientation is concerned with three sets of activities, knowledge of customer wants through market research, responding to market intelligence, and communicating customer wants and needs to suppliers (Kohli \& Jaworski 1990). These activities may be especially difficult when the industry is mainly made up of SMEs. Despite the acknowledged importance of a marketing orientation for SMEs, the precise marketing activities and competencies that contribute most strongly to business performance have still to be identified (Tzokas et al 2001). Given that SMEs are often a major source of employment in many countries (Chee-Chuong Sum 2004), introducing structures and process that enhance market orientation is essential, such as local co-operatives and consortia (see Wagner \& Alderdice 2006 for example). Such institutions assist the SME producer by providing market information and negotiation support (Lamprinopoulou et al 2006) Any move towards co-operation with suppliers will inevitability invoke balance of power 
debates, and ultimately favour the larger business - (Sheridan \& Leibs 1999). This point has been reinforced by others who suggest that although retailers will continue to hold power over suppliers, patronage to their stores continues to be derived from customer demand (Ailloni-Charas 1999).

The reshaping of Western European economies, agriculture and food sectors through globalisation and regionalisation has clear impacts on the political and regulatory environment. Consumers have become more concerned with quality, provenance and local conditions of production and supply (Marsden \& Murdoch 1999). Value- added supply chains might yet be positive defences to fragile rural economies. Creating effective local and regional production may help safeguard rural regions against the prevailing trends of globalisation. Expanding value-added supply chains might deliver advantages in terms of food, health, environmental and other economic and social benefits (Marsden \& Murdoch 1999; Francis et al 2008). In order to promote the food sector at a regional level while addressing prevailing trends towards global markets will require successful implementation of regional associations, networks and supply chains.

To this end the two orientations, supply chain and demand chain, may act synergistically, both contributing to the overall performance of the firm and giving rise to unique competences. According to Mowat and Collins (2000), supply chains in agricultural industries often lack information linking the product quality with consumer behaviour. These industries usually comprise SME producers who do not co-operate and tend to focus on production and technical issues rather than marketing. As Francis et al (2008, p 90) point out from their study of the UK beef industry, "it is not possible to simply adopt a teleological approach of imposing characteristic traits of "leanness" that worked well in different and more collaboratively evolved industries such as automotive." 
Table 1 below summarises characteristics derived from the literature with selected references.

\begin{tabular}{|c|c|c|}
\hline Characteristics & $\begin{array}{l}\text { Supply Chain } \\
\text { Management }\end{array}$ & Market Orientation \\
\hline Philosophy & $\begin{array}{l}\text { Integrating and co- } \\
\text { ordinating (Ellram \& } \\
\text { Cooper 1993) }\end{array}$ & $\begin{array}{l}\text { Integrating and co- } \\
\text { ordinating ( Myles \& } \\
\text { Arnold 1991) }\end{array}$ \\
\hline Purpose & $\begin{array}{l}\text { Satisfy final customer or } \\
\text { end user needs (Taylor } \\
\text { 2006, Cox et al 2007) }\end{array}$ & $\begin{array}{l}\text { Servicing customer } \\
\text { requirements (Rainbird } \\
\text { 2004) }\end{array}$ \\
\hline Focus & $\begin{array}{l}\text { Customer/ consumer } \\
\text { demand ( Canever et al } \\
\text { 2008) }\end{array}$ & $\begin{array}{l}\text { Consumer demand } \\
\text { oriented (Mersend et al } \\
\text { 1999) }\end{array}$ \\
\hline Performance Enhancement & $\begin{array}{l}\text { Facilitates marketing } \\
\text { strategy by improving } \\
\text { efficiency and reducing } \\
\text { costs ( Fisher 1997) } \\
\text { Added value ( Cox et al } \\
\text { 2007) } \\
\text { Improve competitiveness } \\
\text { Reduce Uncertainty } \\
\text { Increase customer } \\
\text { satisfaction ( Zokaei \& } \\
\text { Hines 2007) }\end{array}$ & $\begin{array}{l}\text { Improve customer service } \\
\text { and increase customer } \\
\text { loyalty (Flint 2004) } \\
\text { Differentiation ( Tzokas et } \\
\text { al 2001) } \\
\text { Improve competitiveness } \\
\text { Reduce Uncertainty } \\
\text { Increase customer } \\
\text { satisfaction ( Zokaei \& } \\
\text { Hines 2007) }\end{array}$ \\
\hline Structural Facilitators & $\begin{array}{l}\text { Supplier co-ordination and } \\
\text { supplier development } \\
\text { ( Rich \& Hines 1997) }\end{array}$ & $\begin{array}{l}\text { Local co-operatives } \\
\text { Farmer consortia } \\
\text { (Lamprinopolou et al } \\
\text { 200?, Wagner \& Alderdice } \\
\text { 2006) }\end{array}$ \\
\hline $\begin{array}{l}\text { Behavioural } \\
\text { Characteristics }\end{array}$ & $\begin{array}{l}\text { Business relationships and } \\
\text { networks (Handfield 2004, } \\
\text { Baker 1999) } \\
\text { Trust (Sako 2002) } \\
\text { Power ( Cox et al ???? }\end{array}$ & $\begin{array}{l}\text { Channel relationships and } \\
\text { networks ( Closs \& } \\
\text { Mollenkopf 2004) } \\
\text { Trust (Sako 2002) } \\
\text { Market knowledge ( Kohli } \\
\text { \& Jaworski } 1990\end{array}$ \\
\hline
\end{tabular}

In summary, the literature reinforces the fundamental importance of supply chain and demand chain management to industry growth from both strategic and operational perspectives. However, the challenge is that industries such as agriculture and fisheries are traditionally commodity oriented and production led, emphasising efficiency, high volumes, consistent quality and economies of scale (Grunert et al 2005). Furthermore, these industries often lack reliable information, market orientation and collective behaviour (Collins \& Dunne, 1996, cited in Mowat \& 
Collins 2000). The following section outlines briefly the historical context of the industry under consideration and emphasises the research problem. In order to understand the contemporary issues it is necessary to recount the past developments.

\section{Mediterranean Seabass and Seabream aquaculture from the 1980s}

Fish farming has a long history in the Mediterranean region; with evidence of capture and fattening going back over 2000 years. Industrial seabass and seabream farming has a more recent origin and is rooted in Italian and French laboratory breeding experiments in late 1970s and early 1980s. Development, initially in countries with sheltered coastlines such as Greece and Turkey, attained very modest annual production of only 1,100t by the mid 1980s. Due to pollution, the production of fish fry of sufficient quality and volume presented a major constraint on expansion of the hatcheries necessary to underpin the supply chain. Improved hatchery design and hygiene, resulted in an increased supply of juveniles enabling rapid growth and the emergence of challenges to further viable expansion.

The industry problem was complex and solutions were often difficult to devise and implement given the formative industrial structure of many small independent players. Surmounting technical barriers to fish production encouraged rapid expansion of supplies with subsequent price decline, and ensuing periods of boom and bust which resulted in reduced profitability across the sector. Rapid industry growth raised concerns regarding sustainability and the need to achieve a balance between revenue streams from production, and market demand. In addition, increasing competition and new global markets meant it was imperative that producers acknowledged and responded to requirements and preferences of the end user. Finally, as the more traditional adjacent markets became saturated it was increasingly important to develop efficient local and global supply chains capable of contending with the perishability of the product and increased distance to markets.

Seabass and seabream are produced in most of the twenty-plus Mediterranean countries with the main producers being in Greece, Turkey, Spain, Italy and France. Farmed seabass and seabream producers tend to be SMEs, although some larger organisations have emerged as the sector has developed. Producers are typically 
nationally orientated and with their operations commonly in remote rural coastal communities, with very limited industrial bases. However, they play an important socio-economic role in these peripheral EU locations and in the wider world; food supply from aquaculture is expanding whilst wild fish yields diminish. Indeed one fifth of all EU fish production is now generated from aquaculture, with farmed seabass and seabream comprising some $18 \%$ of this output valued at $€ 400 \mathrm{~m}$, and supporting almost 1,000 companies employing some 8,000 people in 2002 (Anon 2004). Some indication of the rate of change in output is shown in Figures 1 and 2 below. The rate of growth was not even and by 1990 three-quarters of all production was shared by just three players: Greece (42\%), Italy (23\%) and Turkey (12\%).

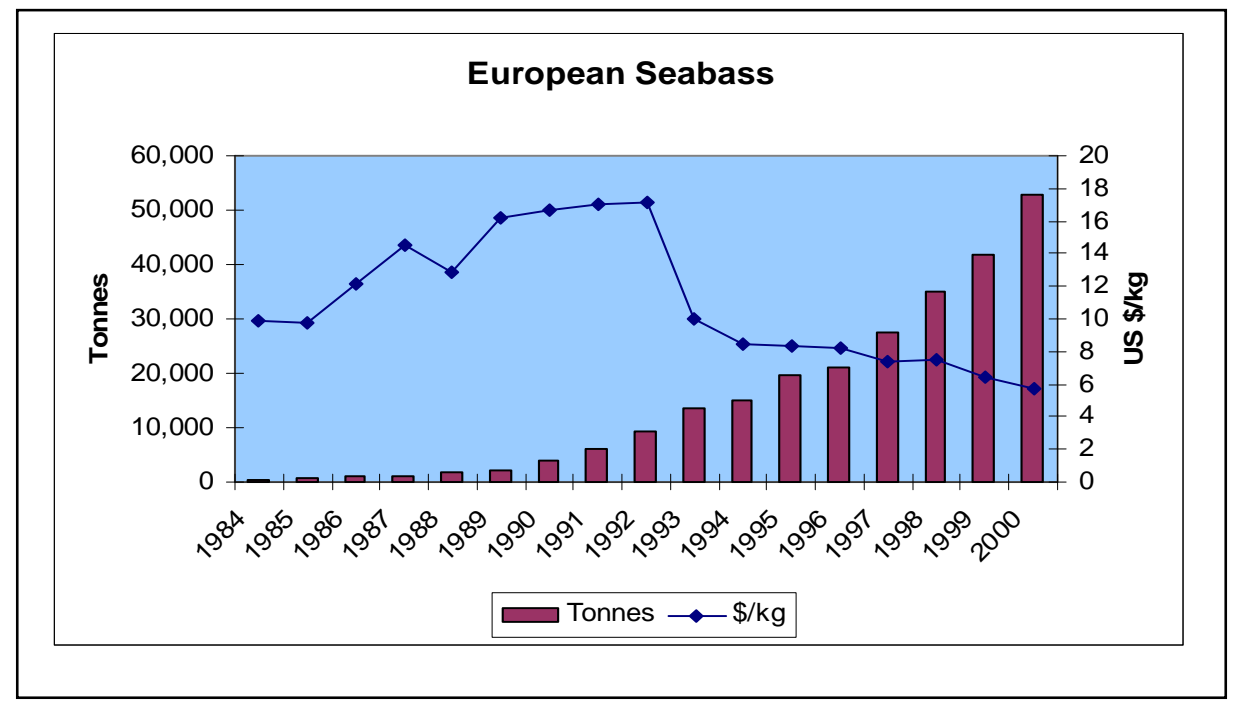

Figure 1: European Seabass production and average value. Source FA0

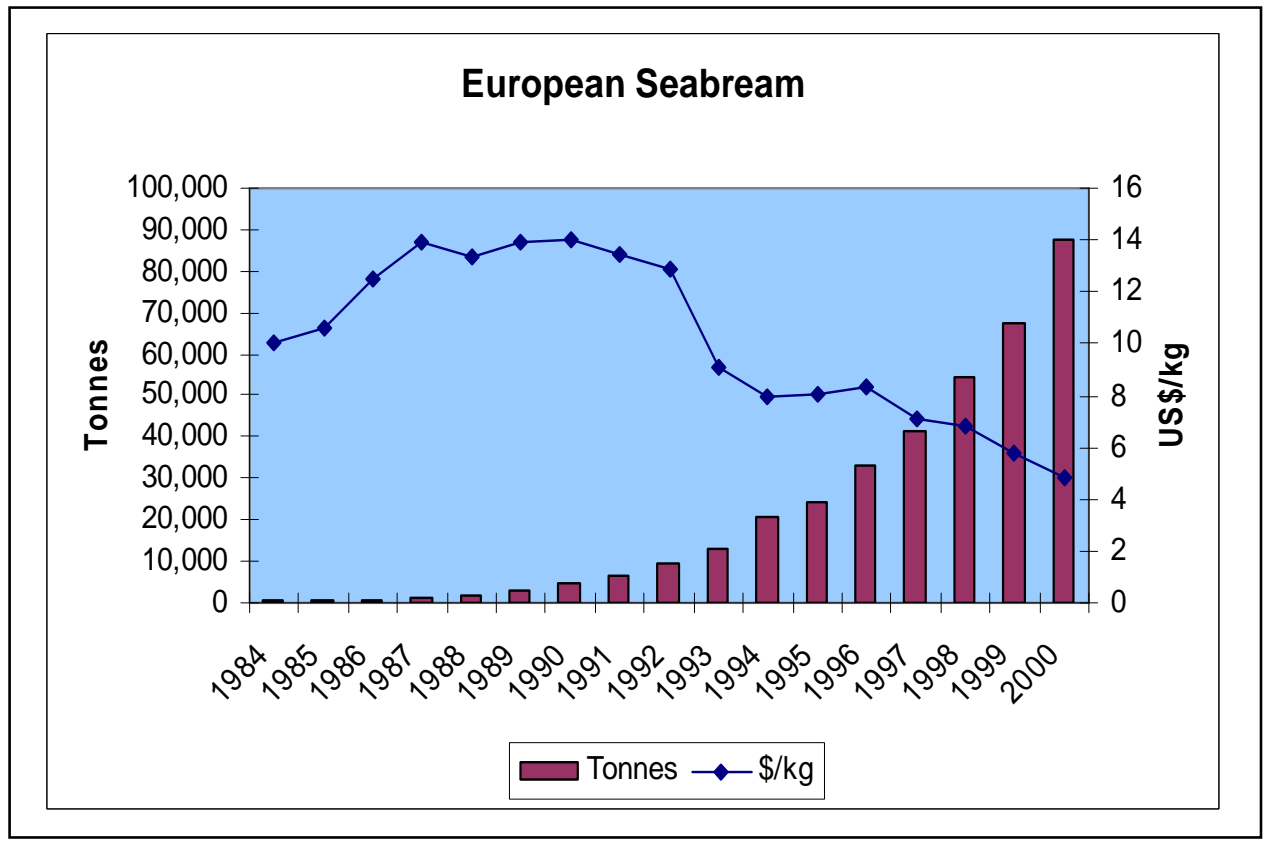

Figur

e 2: 


\section{European Seabream production and average value. Source: FAO}

A second factor influencing production in the 1980s was the procedures for obtaining licences. Establishment of fish farms created new pressures on existing coastal use, notably tourism. In the absence of relevant legislation, and experience of what this might need to cover, consultation with interested parties was commonly contentious and protracted. By the 1990s licence negotiations generally became more straightforward but permissions still invoke hostility in some locations to the present day and environmental impact assessments must satisfy increasingly stringent standards. Most licensing is local and may be subject to localised political forces especially in the face of competing coastal zone pressures.

With entry barriers removed by hatchery technology and an increase in availability of site licences, seabass and seabream producers were well placed in the 1990s to take advantage of financial aid to invest in production. National and EU aid packages began to be available encouraging expansion of the sector not least because of the opportunities it created to diversify and expand the adjacent local economies. Growth is reflected in Figures 1 and 2 above where output reached 144,000t by 2000, from less than 10,000t in 1990. During the 1990s economies of scale were achieved as farm sizes increased and technical progress in fish husbandry continued. Significantly, the production cycle was reduced from 19 to 15 months, enabling faster times to market, and higher feed conversion ratios (FCRs) improved from 2.8 to 2.1 thus requiring less feed cost to produce a marketable fish. Labour productivity also increased. However, by 2000 , it was generally recognised that the major potential gains had been realised and there has been little significant reduction in production costs since. Faced with an apparently solid floor to the reduction in cost of production, any downwards pressure on price would require acceptance by producers of reduced levels of profitability.

\section{Price Crisis 2001-2002}

Unit prices declined, as shown in Figs 1 and 2, from the early 1990s as aquaculture production expanded and these trends culminated in a price crisis in 2001-2002. Whilst many individual producers had foreseen the impact of unlimited expansion, emplacement of mechanisms designed to stimulate further production, albeit for 
laudable socio-political reasons, accelerated the boom and bust cycle. Without market planning, market support or product promotion the expanding imbalance of supply and demand resulted in dramatic falls in profitability within the sector. Many small farmers went bankrupt, with the knock-on effects on employment and income streams in local economies. Whilst SME producers still dominated the sector in terms of numbers, many contended that yet further rationalisation was likely; all the more so unless alternative development strategies were adopted.

A number of factors exacerbate the issues concerned with supply chain planning and reinforced the imperative that global food supply chains need to be managed from both a supply and demand perspective. These include; the high endemic perishability of fish, greater than any other food; the biological basis of supply with a production cycle which effectively precludes many short term responses to market shifts or changes in demand. Any changes in production in response to demand require longer term planning, communication and co-ordination throughout the chain which is unlike manufactured products and other FMCGs where changes may be implemented far more quickly and less expensively. Furthermore, production cycles are long, and lengthier than for some other potentially competing species, and live product inventory incurs ongoing costs through husbandry and feeding. The disparate points of production and consumption and patterns of SME dominance remain an issue even although this is starting to recede as industry concentration emerges giving scale economies.

The foregoing emphasise the uniqueness of the bass and bream supply chain and reinforces Francis et al's (2008), view that it is not always possible to successfully transfer across industries normative rules for leanness and agility. Nevertheless, there is a strategic necessity for those involved in the industry to understand end user requirements and establish effective and efficient global and local customer-facing supply chains. To date there has been little research undertaken within the aquaculture industry from this joint perspective. The next section outlines the methodology and research design undertaken to investigate these issues. 


\section{Methodology and Research Design}

A quantitative methodology was devised to assess production trends and potential of seabass and seabream producers located around the Mediterranean shores in response to a request from the EU DGXIV in 2003. In addition to inclusion of those within the adjacent Mediterranean countries, markets in Northern Europe were included as these are considered to harbour significant potential for market expansion and product diversification.

Published data for individual countries, along with unpublished data held by noncommercial organisations including government agencies, producer associations, research organisations, and universities were scrutinised. The large number of target respondents, based in many different countries, necessitated standard data formats. Templates were designed for data collation, analysis, and presentation according to common methodologies across all participants. The study aimed to identify trends in production volumes, costs, prices, international trade and distribution channels. Barriers to growth were considered including health and hygiene directives, nomenclature and labelling regulations, exchange rates, and import duties. Markets were assessed in terms of their evolution and scope for extension through new market and product development.

Data was validated and triangulated through an iterative process of interpretation and discussion of findings with the research team and key industry players. Where data was deficient, the research team's expertise and knowledge was drawn upon to fill in gaps with realistic analysis which was then corroborated. The outcome was a series of national reports, compiled to a common format, whose findings are next discussed.

\section{Findings}

The survey results showed that in 2002 five countries account for $90 \%$ of production by volume: Greece, Turkey, Italy, Spain and France. Greece, with 57\% of total production was the largest producer, followed by Turkey with 14\%. The Greek production increase has been rapid but with little attempt to coordinate promotion of the product either at home or abroad. This indicates a lack of focus on the final market (Miles \& Arnold 1991). Although a few large companies existed, SMEs still 
dominated. Whilst the large firms had established marketing and sales functions they had not succeeded in bringing any order into the international marketplace.

Turkey, the second largest producer, has an extensive and sheltered coastline suitable for cage farming sites. This natural advantage in terms of production capacity and costs has enabled it to overcome some potentially significant barriers to growth. Exports from Turkey to the EU were banned in 1998 on grounds of quality; a failing which has since been overcome through stricter licensing controls and compliance with EU hygiene standards. Significantly the Turkish sector has grown without EU financial support and has managed largely endogenous nurturement of skills and market intelligence. This development is consistent with supply chain literature where efficiency is encouraged and reducing costs is important as well as a market orientation, with demand driving production (see Sheridan \& Leiba 1999).

The other three main producers, Italy (10\%), Spain (8\%) and France are also significant as markets, with Italy and Spain also being the largest two for seabass and seabream respectively. Small producers dominate Italian production but site and licensing constraints preclude any significant expansion. The regulatory environment has been identified as a major influencer in the implementation of both supply chain management and market orientation at both the strategic and operational levels (see Tzokas et al 2001; Rainbird 2004). In Spain, rationalisation has been more evident and four companies control much of the marketing and distribution. French production expanded in the early 2000s, but site availability and licensing again seem unlikely to permit any further expansion, despite technical progress in fish husbandry. See figures 3 and 4 below.

Insert Table 2: Aquaculture production of seabass 1998-2002 and first sale value Insert Table 3: Aquaculture production of seabream 1998-2002 and first sale value

A number of factors influence the production planning process and include fry production, seasonality and fish size. Most fish are harvested at 300-450g, although some are grown larger to differentiate the product and attempt higher prices. With a production cycle of around 15 months, producers aim to stock in spring and sell in 
summer or autumn, although at times poor cash flow forces producers to sell undersized fish. Seasonality of production varies from country to country, depending on growing conditions and market demand. Much of this is influenced by the biological cycle, but other key factors that influence profitability include disease, escapes and loss of body weight which happens over winter. If the fish spend two winters in the sea, production costs can increase by $0.3 /$ euro/kg due to additional feed costs and losses. To avoid this, fish harvesting commonly begins in July, peaking in the autumn.

Greek producers have a tendency to push small fish into Italian, Spanish and French markets, which clearly may have a negative effect on the reputation of the industry; consumers tend not associate small fish as value for money. As more fish are marketed, often on price promotions through supermarkets, they tend to become commodity foods rather than high quality, high value produce. Greece and Spain have so become locked into production cycles which encourage oversupply in the autumn and imbalance in the markets. Those countries with warmer winter temperatures such as Turkey, Cyprus and Malta do not suffer the same problems and thus have a more stable production schedule.

A critical factor stimulating the growth of seabass and seabream was the innovation of large scale hatcheries, which enabled greater control over fry production and removed reliance upon the collection of wild fry. Scale economies also emerged enabling a reduction in costs; for example fry costs reduced from €0.48 in 1990 to $€ 0.22$ in 2003 for seabream and from $€ 0.42$ to $€ 0.21$ for seabass. These reductions are significant since, even at this lower level fry, still represent $15-20 \%$ of production costs. Together with feed and labour, these three components account for about $70 \%$ of total production costs. With current technology, it seems unlikely that further significant efficiency gains can be realised and all producers thus have similar cost structures, with the exception of labour, notably in Turkey. New entrants to the sector were encouraged by apparently buoyant conditions and the ready availability of grants and loans encouraged inexperienced small operators to start farms. Subsequent attempts to reduce costs have been made through mergers especially in Spain and Greece. But it remains to be seen to what extent the industrial structure will follow the models of greater integration found within other intensive aquaculture systems. 
Improvements in production capacity however proved to be something of a doubleedged sword and between 2001 and 2002 there was a major price collapse, especially in Greece, as fish supply exceeded demand. The supply-led focus of the sector's development, combined with a business philosophy based upon sales rather than marketing, resulted in significant declines in performance on the international market, The fall in prices was especially severe for many of the small producers who, lacking any financial reserves, tried to sell their way out of a cash flow problem but often with small grade sizes which simply lowered market prices further still. This behaviour was also encouraged by large hatchery companies selling large volumes of fry in a drive to improve their financial performance. As a consequence, a ratchet effect of increasing volumes of ever-smaller fish generating lower unit prices, thus requiring higher sales volumes, was set in motion and the market's free-fall had no supporting promotional mechanisms, or strategy in place, to attenuate the decline.

The supply and demand imbalance was manifest in all countries and the reduced profitability forced structural changes, with many small operators being taken over by larger companies, or exiting the sector. Nonetheless SMEs still retained a dominant role within the sector and this fragmented structure may pose particular challenges for the adoption of more emphasis upon market orientation.

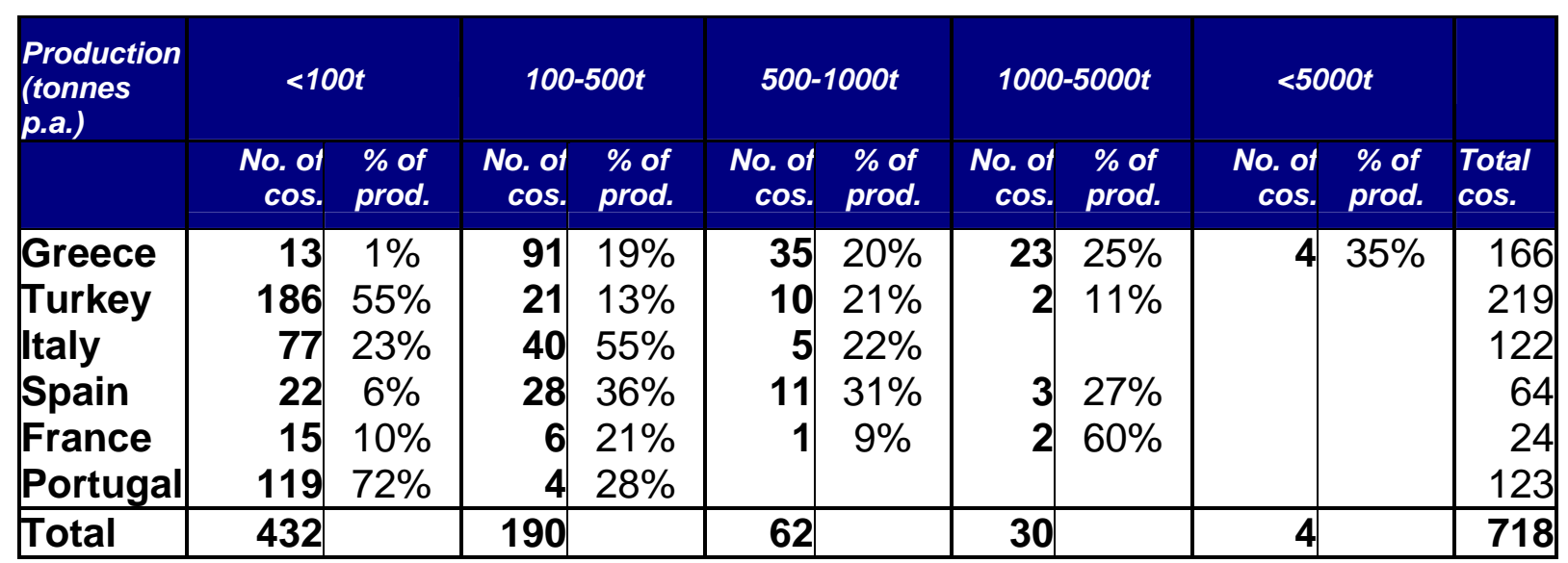

Table 4: Industry structure by company size (Anon 2004: 29) 


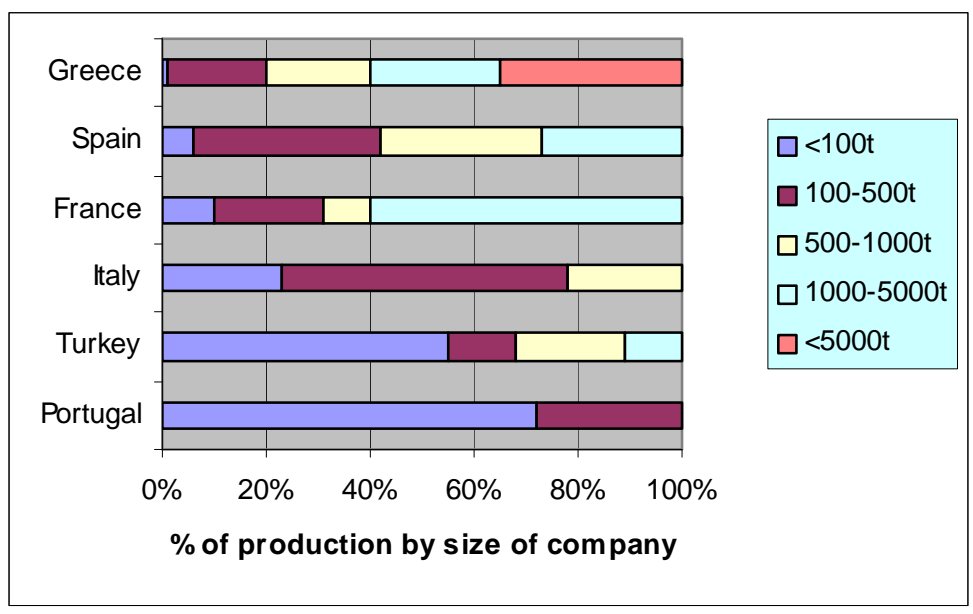

Figure 3: Industry composition by company size (Anon 2004: p30)

The future development of the industry will be dependent on site availability, cost of production, economic stability and market demand. The following table 5 summarises the main findings related to supply chain and market orientation from the study.

\begin{tabular}{|l|l|l|}
\hline Supply Chain Issues & Demand and Market Issues & Umbrella Issues \\
\hline $\begin{array}{l}\text { Lack of co-operation amongst } \\
\text { local and international } \\
\text { producers }\end{array}$ & $\begin{array}{l}\text { Lack of differentiation and } \\
\text { development }\end{array}$ & $\begin{array}{l}\text { Lack of co-ordinated } \\
\text { national strategic plan } \\
\text { for aquaculture. Poor } \\
\text { industry administration }\end{array}$ \\
\hline $\begin{array}{l}\text { Little scope in the short term to } \\
\text { reduce production costs }\end{array}$ & $\begin{array}{l}\text { Growing public awareness of } \\
\text { negative effects of aquaculture }\end{array}$ & $\begin{array}{l}\text { Lack of co-operation } \\
\text { between government and } \\
\text { industry on R\&D }\end{array}$ \\
\hline $\begin{array}{l}\text { Unregulated supply causing } \\
\text { imbalance in the market }\end{array}$ & $\begin{array}{l}\text { Need to develop / increase } \\
\text { consumption in all markets }\end{array}$ & $\begin{array}{l}\text { Competition from an } \\
\text { emerging range of other } \\
\text { farmed species. }\end{array}$ \\
\hline $\begin{array}{l}\text { Industry rationalisation and } \\
\text { scope for development of } \\
\text { efficient production systems }\end{array}$ & $\begin{array}{l}\text { Need to develop branding } \\
\text { strategies and better } \\
\text { promotional tactics }\end{array}$ & \\
\hline $\begin{array}{l}\text { Need to develop quality } \\
\text { schemes }\end{array}$ & & \\
\hline $\begin{array}{l}\text { Requirement for more efficient } \\
\text { distribution systems to } \\
\text { accommodate industry growth }\end{array}$ & & \\
\hline
\end{tabular}

Table 5: Summary of Findings

Analysis of the sector, generated from the data gathered, highlights a number of problematic areas in addition to its structural characteristics. In particular, there is a 
virtual absence of market-oriented mechanisms such as effective quality schemes, promotional activities, and product differentiation to deliver more precise satisfiers of market demands. Yet on a more positive note, the sector has been found to have some emergent strength and within the wider aquatic foods markets there is general recognition of significant opportunities that the sector could capitalise upon.

\section{Analysis and Discussion}

From a synthesis of the data, the main weaknesses appear to be the inter-relationships between supply channel members and inadequate information flows about changing consumer demands within the market (see Flint 2004). Lack of co-ordination and poor information sharing throughout supply chains ensures that upstream suppliers have little market information and so operate in an uncertain and reactive environment (AlMundimigh et al 2004; Handfield and Nichols Jr 2004; Rainbird 2004). Information sharing among channel members is critical to understanding customers' wants, especially in markets where the final consumers can only differentiate homogeneous product through the many dimensions of quality, provenance and branding (Tzokas et al 2001). Relationships in the supply chain and co-operation between customers and suppliers, can influence the degree of information sharing within the chain (see Rich \& Hines 1997; Sheriden and Leibs 1999).

Upstream suppliers can play a considerable part in adapting raw material to different demands of the heterogeneous consumer (Handfield \& Nichols Jr 2004). This is arguably of particular importance in the context of fish where quite disparate preferences and patterns of consumption are found within the European markets

(Paquotte et al 2002). This reflects not only the evolution of many complex sociocultural phenomena but also the versatility and diversity of the raw material when compared to many other competing protein substitutes (Young \& Muir, 2002). Clearly, there is a need for the SME producers to be aware of the end consumer requirements and to avail themselves of competencies in product and market diversification and development. In addition, there must also be a belief that such market orientation will bring about real gains in their profitability. Such a global supply and marketing strategy may be difficult to implement (Closs \& Mollenkopf 2004), all the more so when traditionally this has seemingly not been perceived to be necessary. This might also suggest that a corollary may be a more competitive edge 
honed through greater focus upon the human resources employed, especially nurturing appropriate skills and competences in the SMEs (Chee-Chuong Sum et al 2004). Attainment of specific national and regional policies may be required to support the producers (Flint 2004), particularly as national cultures, business practices, regional policies and regulatory environments may be interpreted in different ways.

Logistics networks are increasingly complex and often imbalanced, notably at the retail level. For SMEs to succeed it is vital that signals generated at all points of exchange are communicated within the chain, if product delivery and handling are to be effective and efficient. As has been noted elsewhere, there is often considerable scope to improve this aspect of the industry as the channel adds value as well as the product (Sheridan \& Leibs 1999; Akkermans \& Bogerd 1999). More specifically each of the earlier research questions are addressed as follows;

Q1 How might the SME Mediterranean aquaculture producers move from traditional high output production systems to become more market oriented?

In order to achieve a market orientation, professional and coordinated marketing is imperative so that companies can get closer to customers and consumers and better understand their needs (Sheridan \& Leibs 1999; Grunert et al 2005). Rationalisation of the industry and supply chains, nationally and internationally seems necessary and as well as provision of support for smaller producers through supplier development programmes, supplier associations, and supplier cooperatives (see Rich \& Hines 1997). Such initiatives encourage industry producers to engage with other members of the supply chain, improve market intelligence and assist in the delivery of products required. This study highlights the pivotal role that the SME producer plays in rural economies, in terms of rural employment; industry growth and technological development (see Marsden et al 1999; Chee-Chuong Sum et al 2004).

The disparate points of production and consumption, in an emergent era of rising energy costs and greater environmental awareness, pose many challenges for remote food producers. The reduction of food miles and emphasis of sustainability criteria, for example by promoting locally grown products rather than imports, can be achieved through government approved quality assurance schemes and other communications. Indeed more recently, the Greek sector has sought to place greater 
attention upon the domestic market for this very reason (Sudborough, 2007). But clearly some degree of reliance is certain to remain and thus transportation and distribution are essential to reduce space /time costs and can be best achieved through structural integration, operational co-ordination and information sharing (see Closs \& Mollenkopf 2004). Global transportation routes require efficient and well coordinated supply chain structures to create seamless and effective transportation and logistical performance. Here transportation and the skills of third party providers take a lead role in the integration of the supply chain flow (see Akkermans \& Bogerd 1999).

Q2 How might the supply chain for this increasingly important, yet highly perishable, food become aligned with demand to promote delivery of sustainable and quality products sought by consumers?

Many of the points made in addressing the previous question also apply here. More effective management of the industry can be achieved through streamlining, rationalisation and regulations. The outcome of the price crisis, caused by an imbalance between supply and demand in all countries, was business closures through reduced profitability. Accordingly, utilisation of accurate market research data and tailoring production would help to address the supply and demand problems. In turn, this could feed into product promotion and new product development to meet end consumer requirements in targeted countries and markets, as well as reducing reliance on exports. Consistency in quality, freshness and provenance are often compromised due to pooling of fish at distribution centres, outwith the country of origin (see Akkermans \& Bogerd 1999). However, with apposite investment in logistical infrastructure, such as temperature controlled transportation, traceability systems and accurate delivery using routing and scheduling technology (see Akkermans \& Bogerd 1999), consistent delivery is achievable, and, more disconcertingly, is evident from competitor practice.

There is evidence from the study that consumers, in some market segments of the countries explored, are willing to pay a higher price for the product (Paquotte et al, 2002). Here the role of the multiple food retailers is important. In all countries studied, independent specialist fishmongers are decreasing and the multiple retail chains increasingly dominate the retail market for fish (see also Boselie et al 2003). 
The role of the multiple is critical in terms of maintaining the status of speciality foods and introducing range extensions such as seabass and seabream. However, especially where the product or provenance is new, it is critical that consumer expectations of fish attributes, such as freshness and other quality cues, are delivered. Evidence suggests that, in some cases at least, retail buyers often place greater emphasis upon low price through promotional selling than other concerns such as quality. Apart from risking the immediate generation of negative perceptions of the fish product, it may also skew its longer term position in the mind of the consumer.

More favourable reactions might also be encouraged through some focus upon the food service channels where consumers' uncertainties and reservations about new species can be resolved through the meal solutions provided. This strategy has been found to be especially useful where new markets are being developed for products new to consumers. For example, the Norwegian Seafood Export Council has successfully introduced salmon in China where red fish flesh was alien to traditional Chinese cooking (Young \& Muir, 2002), In such new product launches, the concept of understanding market demand is all the more trenchant, since it reflects a need for an accompanying ability to interpret and identify lateral product solutions, in addition to those more immediately evident.

Q3 How might such changes be promulgated to help secure the sector's future sustainability?

Over-production was the prime driver for the dramatic fall in prices observed. Excess supply was exacerbated by readily available grants which encouraged expansion by new entrants with little knowledge of the industry, along with others. More trenchant perhaps was the absence of an explicit link of fiscal policy with any strategy for the market and its developments. A number of government and EU policy initiatives are necessary to bring order to the sector and reduce uncertainty. At the supranational level, there is a clear need for co-ordinated and integrated national aquaculture and coastal zone management plans (see Closs \& Mollenkopf 2004). These should help reduce conflicting actions and promote compliance through implementation, monitoring and control in conjunction with ongoing planning reviews of changing 
market needs. For such policy to be effective, a more holistic perspective on the chain clearly must be adopted.

By definition, such an holistic perspective must also embrace contemporary and emergent developments in other competing fish species and food products, beyond just seabass and seabream. With the earlier noted pre-eminent growth in aquaculture and its constituent mix of existing and new species, strategic management of any one sector to identified positions within the market is difficult enough, without the handicap of not having first adequately defined the targets. The inference is thus that changes, consistent with the earlier research questions, must at the very least incorporate a more systematic planning process in engaging with future markets. It is also evident that answers to these three key research questions are both interconnected and interdependent with a range of other factors as well.

\section{CONCLUSION}

Central to the creation of a more sustainable seabass and seabream sector is the need to nurture a closer relationship between production and the dynamic context of market demand. Whilst oceanographic conditions largely determine the natural production base within the Mediterranean, there are many competing food markets around the world that are supplied by other fish and non-fish products. Coupled with the endemic constraints of fish as the most perishable of all foods, these are especially demanding challenges to the establishment of effective and efficient global and local supply chains, as well as a correct understanding of end user requirements.

The global marketplace for seabass and seabream is complex, even although the basic product is quite homogeneous and standardised. To date producers have demonstrated little regard for the format of the product or the requirements of the end consumer. Most of the technical production problems that faced producers in the early days have been overcome and this, along with the provision of subsidies has focused producers on increased output volume. The effect of this has been to reduce the cost of the product, but with reduced overall profitability, which could not be ameliorated through economies of scale. Research and development in the industry has been technically focussed and the general lack of market orientation has contributed to the crisis in the industry. 
One possible route to maintain and promote profitability could be through the use of advanced market information systems that would allow better production planning. Adoption and implementation of such systems must be grounded in a sound understanding of current and emerging market demands and a clear understanding of the supply chain architecture and relationships between channel members. Given the fragmentation of the industry and the numerous small players, streamlining the supply chain may be a long and complex task. Ideally, small producer sustainability is dependent upon a solid understanding of the market, in order to produce what the market wants in terms of both volume and product format. Greater efficiency and traceability in food supply chains is imperative, however issues remain in terms of how SME producers can be incorporated into a dominant global supply chain, or become adaptive and adhere to localised self-controlled supply chains.

Experience from other farmed fish sectors has tended to exhibit a pattern of consolidation and increased concentration over time as the sector matures. This has been notable in farmed Atlantic salmon (Bjørndal et al 2003) and tilapia, (Muir \& Young, 2000) amongst others (Lem, 2007). More recent evidence vindicates the view that seabass and seabream are likely to head in the same direction (Intrafish, 2009) As consolidation occurs, the SMEs tend to be taken-over or exit the sector. A residual element, often comprising the more fore-sighted and entrepreneurial, may tend to diversify into other emergent species in the hope of gaining from the early-launch honeymoon period of initially higher prices which markets are likely to pay for a novel species. In the case of seabass and seabream, evidence suggests a rather similar pattern has emerged with new licences being restricted to those investing in new species and increased concentration of seabass and seabream producers (Papageorgiou, 2007). If this continues, a more diversified base may well provide the cushion to soften the adverse impacts of future fluctuations in price. So long as the range of diversified species, and the products delivered therefrom, remains consistent with a business philosophy of greater market orientation, the role of any future EU policy review may be both less onerous and reactive.

Finally, although some industry rationalisation has occurred, the predominant producer remains the SME. From a sectoral policy perspective it is therefore arguably imperative that SME interests are supported and horizontal collaboration nurtured through well organised supplier associations and supplier development programmes. 
Local co-operative consortia and supplier hubs can assist the SME with market research and valuable information regarding end-user preferences and established routes to market. The study emphasises the importance of communication to facilitate horizontal co-ordination and highlights barriers to collective action facing small geographically dispersed firms. These challenges cannot lie dormant if the sector is to realise its potential.

\section{References}

Akkermans, H. \& Bogerd, P. (1999), "Virtuous and vicious cycles on the road towards international supply chain management", International Journal of Operations and Production Management, Vol. 19 No. 5/6, pp. 565-581.

Ailloni-Charas, D. (1999), “The supply chain versus the demand line”, Brandweek, Vol. 40 No 17, pp 36-38

Al-Mudimigh, A. S., Zairi, M., Moneim, A., \& Ahmed, M. (2004), "Extending the concept of supply chains: the effective management of value chains", International Journal of Production Economics, Vol. 87, pp. 309-320.

Anon. (2004) "Study of the market for aquaculture produced seabass and seabream species". Report produced for the European Commission DG XIV http://ec.europa.eu/fisheries/publications/studies/aquaculture_market_230404.pdf

Baker, M.J. (1999), “Editorial”, Journal of Marketing Management, Vol. 15, pp. 211214

Bello, D. C., Lohtia, R., \& Sangtani, V. 2004, "An institutional analysis of supply chain innovations in global marketing channels", Industrial Marketing Management, Vol. 33 No. 1, pp. 57-62.

Bjørndal, T., Knapp, G.A., and Lem, A. (2003). Salmon - A Study of Global Supply and Demand. FAO Globefish Report 77

Boselie, D., Henson, S., \& Weatherspoon, D. (2003), "Supermarket procurement practices in developing countries: redefining the roles of the public and private sectors”, American Journal of Agricultural Economics, Vol. 85 No 5, pp. 1155-1161

Canever Duarte, M. Van Rtijp, H.C.M. \& Beers, G. (2008), The emergent demand chain: key features and illustration from the beef business, Supply Chain Management: An International Journal, Vol. 13, No. 2, pp. 104-115

Cambra-Fierro, J. and Polo-Redondo, Y, (2008), Creating satisfaction in the demandsupply chain: the buyers perspective. Supply Chain Management: An International Journal, Vol. 13 No. 3, pp 211-224 
Chee-Chuong Sum, Shih-Ju Kow, L., \& Cheng-Sheng Chen (2004), "A taxonomy of operations strategies in high performing small and medium enterprises in Singapore", International Journal of Operations and Production Management, Vol. 24 No. 3, pp. 321-345.

Closs, D. \& Mollenkopf, D. A. (2004), "A global supply chain framework", Industrial Marketing Management.

Cox, A, Chicksand, D. \& Tong Yang, (2007), Alignment of sourcing with marketing and branding strategies, Supply Chain Management: An International Journal, Vol. 12 No. 5, pp. 321-333

Ellram, L. and Cooper, M. (1993), "Characteristics of supply chain management and the implications for purchasing and logistics strategy", International Journal of Logistics Management, Vol. 27 No.3, pp. 2-8

FAO (2006), State of World Aquaculture 2006. Fisheries Technical Paper 500.

Fisher, M.L. (1997), "What is the right supply chain for your product?” Harvard Business Review, Vol. 77 No. 2, pp. 133-141

Flint, D. J. (2004), "Strategic marketing in global supply chains", Industrial Marketing Management, Vol. 33 No. 1, pp. 45-50.

Francis, M. Simons, D. \& Bourlakis, M. (2008), Value chain analysis in the UK beef foodservice sector, Supply Chain Management: An International Journal, Vol.13 No 1, pp 83-91

Grunert, K.G., Jeppesen, L.F., Jespersen, K.R., Sonne, A., Hansen,K., Trondsen, T and Young, J.A.(2005), "Market orientation of value chains: a conceptual framework based on four cases studies from the food industry", European Journal of Marketing, Vol. 39 No. 5/6, pp. 428-455

Handfield, R. B. \& Nichols Jr., E. L. ( 2004), "Key issues in global supply base management", Industrial Marketing Management, Vol. 33 No. 1, pp. 29-35.

Hooley,G.J., Lynch, J. and Shepherd, J. (1990), “The marketing concept: putting theory into practice”. European Journal of Marketing, Vol. 24 No 9, pp.7-23

Holmstrom, J., Hoover, W.E. Jr, Louhiluoto,P., Vasara, A. (2000), "The other end of the supply chain”, McKinsey Quarterly, Vol 2 No 1, pp. 63-79

Intrafish, (2009) http://www.intrafish.no/global/news/article240732.ece accessed $18 / 02 / 09$

Kohli, A.K. and Jaworski, B.J. (1990), "Market orientation: the construct, research propositions, and managerial implications”, Journal of Marketing, Vol 54, April, pp. 201-233 
Lamprinopoulou, C., Tregear,A and Ness, M. (2006), “Agrifood SMEs in Greece: the role of collective action”. British Food Journal, Vol 108 No. 8, pp 663-676.

Lem, A. (2007) Seafood production and international trade: Global trends. Marketing of Seafood Products: Trends and Challenges Workshop. Zaragoza. 12-16 November.

MacMillan, I.C., 7 McGrath, R.G. (1997), "Discovering new points of differentiation”, Harvard Business Review, Vol. 75, July/August pp. 133

Marsden, T. \& Murdoch, J and Morgan,K. (1999), "Sustainable agriculture, food supply chains and regional development", International Planning Studies, Vol. 4, No. 3, pp. 295-304.

Miles, M.P. and Arnold, D.R. (1991),’The relationship between marketing orientation and entrepreneurial orientation”, Entrepreneurship Theory and Practice, Vol. 15, pp. 49-65

Morash, E.A. \& Clinton, S.R., (1997), "The role of transportation capabilities in international supply chain management”, Transportation Journal, vol. 36 (3), pp 5-18

Mowat, A., and Collins, R. (2000), "Consumer behaviour and fruit quality: supply chain management in an emerging industry", Supply Chain Management: An International Journal, Vol. 5 No 1, pp 45-54.

Muir, J.F. \& Young, J.A. (1999) Strategic issues in new species development for aquaculture. 85-96 in Elsevier Biofutures Series. XXXIII International Symposium on New Species for Mediterranean Aquaculture, Elsevier.

Muir, J.F. \& Young, J.A. (2000) "Marketing and Economics of Tilapia” Ch 12, pp. 447-487, In Beveridge, M. \& McAndrew, B. (Eds) Tilapias: biology and exploitation Kluwer Academic Publishers

Ottesen, G.G. (2006), “Do upstream actors in the food chain know end-users' quality perceptions? Findings from the Norwegian salmon farming industry", Supply Chain Management: An International Journal, Vol. 11 No 5, pp 456-463

Papageorgiou, P. (2007) http://www.intrafish.no/global/news/article137296.ece 20th June

Paquotte, P.,Mariojouls, C. and Young, J.A.(2002), "Seafood market studies for the introduction of new aquaculture products”. Cahiers Options Mediterraneennes. Vol 59, pp. 377. CIHEAM, Zaragoza

Rainbird, M. (2004), "Demand and supply chains: the value catalyst”, International Journal of Physical Distribution and Logistics Management, Vol 34 No. 3/4, pp. 230250

Rich, N. \& Hines, P. (1997), "Supply chain management and time based competition: the role of the supplier association", International Journal of Physical Distribution and Logistics Management, Vol. 27, No. 3/4, pp. 210-225. 
Ring, P. \& van de Ven, A. (1992), "Structuring co-operative relationships between organisations”, Strategic Management Journal, Vol. 13 No. 7, pp. 483-498

Sako, M. (2000), "Does trust improve business performance”, in Lane, C. and Bachman, R. (eds), Trust within organisations: conceptual issues and empirical applications, Oxford University Press, Oxford, pp 88-117

Sheridan, J. H., and Leibs, S. (1999), “Managing the Chain”, Industry Week, Vol. 248 No. 16, pp.15-43

Sin, L.Y.M. Tse, A.C.B. Yau, O.H.M. Chow, R.P.M. and Lee, J.S.Y. (2005), "Market orientation, relationship orientation, and business performance: the moderating effects of economic ideology and industry type”, Journal of International Marketing, Vol. 13 No 1, pp. 36-57

Sudborough, B. (2007) Selonda Fisheries. Personal communication November

Taylor, D.H. (2006), "Demand Management in agri-food supply chains: An analysis of the characteristics and problems and a framework for improvement". The International Journal of Logistics Management. Vol 17 No 2, pp. 163-186

Taylor, D.H., and Fearne, A., (2006). "Towards a framework for improvement in the management of demand in agri-food supply chains”, Supply Chain Management: An International Journal, Vol. 11 No. 5, pp 379-384

Tzokas, N., Carter,S. and Kyriazopoulos, P. (2001), "Marketing and entrepreneurial orientation is small firms", Enterprise and Innovation Management Studies, Vol. 2 No. 1, pp.19-33

Van der Vorst, J.G.A.J., and Beulens, A.J.M. (2002), "Indentifying sources of uncertainty to generate supply chain redesign", International Journal of Physical Distribution and Logistics Management. Vol. 32 No. 6, pp 409-430

Voss,C., Alstrom,P and Blackmon,K. (1997), "Benchmarking and operational performance: some empirical results”. International Journal of Operations and Production Management, Vol. 17 No. 10, 1046-58

Wagner, B.A. and Aldredice, A.D.G. (2006). "Managing the distribution channel: the case of Scot Trout and Salmon”, Supply Chain Management: An International Journal, Vol. 11 No. 2, pp. 104-107

Webster, F. (1979), Industrial marketing strategy, John Wiley \& Sons, New York

Young, J.A. \& Muir, J.F. (2002) Marketing Fish Ch.3 37-60 In Hart, P.J.B \& Reynolds, J.D.(Eds) Handbook of Fish and Fisheries Vol II Blackwell Science. 
Zokaei, K., and Hines, P. (2007), “Achieving consumer focus in supply chains”, International Journal of Physical Distribution and Logistics Management, Vol. 37 No 3, pp 223-247 


\begin{tabular}{|c|c|c|c|c|c|c|c|c|c|c|c|c|c|c|c|}
\hline & $\begin{array}{r}\text { Volume } \\
\text { (tonnes) }\end{array}$ & $\begin{array}{r}1998 \\
\text { Value } \\
\left(€^{\prime} 000\right)\end{array}$ & $\begin{array}{l}\text { Value } \\
(€ / k g)\end{array}$ & $\begin{array}{r}\text { Volume } \\
\text { (tonnes) }\end{array}$ & $\begin{array}{r}1999 \\
\text { Value } \\
\left(€^{\prime} 000\right)\end{array}$ & $\begin{array}{l}\text { Value } \\
(€ / k g)\end{array}$ & $\begin{array}{r}\text { Volume } \\
\text { (tonnes) }\end{array}$ & $\begin{array}{r}2000 \\
\text { Value } \\
\left(€^{\prime} 000\right)\end{array}$ & $\begin{array}{l}\text { Value } \\
\text { (E/kg) }\end{array}$ & $\begin{array}{r}\text { Volume } \\
\text { (tonnes) }\end{array}$ & $\begin{array}{r}2001 \\
\text { Value } \\
\left(€^{\prime} 000\right)\end{array}$ & $\begin{array}{l}\text { Value } \\
\text { (E/kg) }\end{array}$ & $\begin{array}{l}\text { Volume } \\
\text { (tonnes) }\end{array}$ & $\begin{array}{r}2002 \\
\text { Value } \\
\left(€^{\prime} 000\right)\end{array}$ & $\begin{array}{l}\text { Value } \\
(€ / k g)\end{array}$ \\
\hline Greece & 25,068 & 139,378 & 5.56 & 25,137 & 123,171 & 4.90 & 29,419 & 131,209 & 4.46 & 37,706 & 153,463 & 4.07 & 44,439 & 170,201 & 3.83 \\
\hline Turkey & 8,680 & 59,024 & 6.80 & 12,000 & 62,400 & 5.20 & 17,877 & 80,447 & 4.50 & 15,546 & 54,411 & 3.50 & 14,339 & 49,470 & 3.45 \\
\hline Italy & 5,850 & 43,758 & 7.48 & 7,200 & 52,128 & 7.24 & 8,100 & 54,351 & 6.71 & 9,500 & 59,470 & 6.26 & 9,600 & 61,440 & 6.40 \\
\hline France & 2,500 & 19,825 & 7.93 & 3,150 & 22,586 & 7.17 & 3,600 & 23,868 & 6.63 & 3,000 & 17,400 & 5.80 & 3,500 & 19,250 & 5.50 \\
\hline Spain & 936 & 7,675 & 8.20 & 1,227 & 7,438 & 6.06 & 1,837 & 10,875 & 5.92 & 2,306 & 12,342 & 5.35 & 3,180 & 16,568 & 5.21 \\
\hline Croatia & 1,100 & 7,854 & 7.14 & 1,200 & 8,892 & 7.41 & 1,400 & 12,124 & 8.66 & 1,600 & 13,632 & 8.52 & 1,600 & 13,632 & 8.52 \\
\hline Portugal & 800 & 5,744 & 7.18 & 1,120 & 7,269 & 6.49 & 1,070 & 6,153 & 5.75 & 1,350 & 7,169 & 5.31 & 1,300 & 6,903 & 5.31 \\
\hline Tunisia & 300 & 2,412 & 8.04 & 184 & 1,619 & 8.80 & 198 & 2,035 & 10.28 & 461 & 4,333 & 9.40 & 648 & 6,091 & 9.40 \\
\hline Cyprus & 206 & 1,432 & 6.95 & 298 & 1,994 & 6.69 & 299 & 1,854 & 6.20 & 383 & 2,279 & 5.95 & 422 & 2,739 & 6.49 \\
\hline Malta & 80 & 396 & 4.95 & 80 & 315 & 3.94 & 234 & 728 & 3.11 & 206 & 651 & 3.16 & 300 & 948 & 3.16 \\
\hline Morocco & 563 & 3,249 & 5.77 & 275 & 1,430 & 5.20 & 250 & 1,538 & 6.15 & 202 & 1,000 & 4.95 & 200 & 990 & 4.95 \\
\hline Israel & 30 & 321 & 10.71 & 26 & 289 & 11.11 & 150 & 1,199 & 7.99 & 150 & 1,262 & 8.41 & 150 & 1,262 & 8.41 \\
\hline Egypt & 89 & 721 & 8.10 & 37 & 259 & 7.00 & 120 & 816 & 6.80 & 125 & 750 & 6.00 & 130 & 689 & 5.30 \\
\hline Total & 46,202 & 291,788 & 6.32 & 51,934 & 289,789 & 5.58 & 64,554 & 327,195 & 5.07 & 72,535 & 328,162 & 4.52 & 79,808 & 350,182 & 4.39 \\
\hline
\end{tabular}

Table 2 Aquaculture production of seabass 1998-2002 by volume and first sale value 
Table 3. Aquaculture production of seabream 1998-2002 by volume and first sale value

\begin{tabular}{|c|c|c|c|c|c|c|c|c|c|c|c|c|c|c|c|}
\hline & \multicolumn{3}{|c|}{1998} & \multicolumn{3}{|c|}{1999} & \multicolumn{3}{|c|}{2000} & \multicolumn{3}{|c|}{2001} & \multicolumn{3}{|c|}{2002} \\
\hline & $\begin{array}{r}\text { Volume } \\
\text { (tonnes) }\end{array}$ & $\begin{array}{r}\text { Value } \\
(€ ' 000)\end{array}$ & $\begin{array}{l}\text { Value } \\
\text { (€/kg) }\end{array}$ & $\begin{array}{r}\text { Volume } \\
\text { (tonnes) }\end{array}$ & $\begin{array}{r}\text { Value } \\
\left(\epsilon^{\prime} 000\right)\end{array}$ & $\begin{array}{l}\text { Value } \\
(\epsilon / k g)\end{array}$ & $\begin{array}{r}\text { Volume } \\
\text { (tonnes) }\end{array}$ & $\begin{array}{r}\text { Value } \\
\left(\epsilon^{\prime} 000\right)\end{array}$ & $\begin{array}{l}\text { Value } \\
(\epsilon / \mathrm{kg})\end{array}$ & $\begin{array}{r}\text { Volume } \\
\text { (tonnes) }\end{array}$ & $\begin{array}{r}\text { Value } \\
\left(\epsilon^{\prime} 000\right)\end{array}$ & $\begin{array}{l}\text { Value } \\
\text { (€/kg) }\end{array}$ & $\begin{array}{r}\text { Volume } \\
\text { (tonnes) }\end{array}$ & $\begin{array}{r}\text { Value } \\
\left(\epsilon^{\prime} 000\right)\end{array}$ & $\begin{array}{l}\text { Value } \\
(\epsilon / \mathrm{kg})\end{array}$ \\
\hline Greece & 33,230 & 170,802 & 5.14 & 33,321 & 137,949 & 4.14 & 38,997 & 166,127 & 4.26 & 49,982 & 176,436 & 3.53 & 58,907 & 209,709 & 3.56 \\
\hline Spain & 4,933 & 32,558 & 6.60 & 6,117 & 35,234 & 5.76 & 8,242 & 46,345 & 5.62 & 9,833 & 42,788 & 4.35 & 10,960 & 44,684 & 4.08 \\
\hline Turkey & 10,150 & 61,915 & 6.10 & 11,000 & 51,700 & 4.70 & 15,460 & 61,840 & 4.00 & 12,939 & 41,405 & 3.20 & 11,681 & 40,884 & 3.50 \\
\hline Italy & 5,500 & 34,045 & 6.19 & 5,700 & 38,247 & 6.71 & 6,000 & 38,760 & 6.46 & 7,800 & 42,276 & 5.42 & 9,000 & 50,400 & 5.60 \\
\hline Israel & 1,643 & 17,597 & 10.71 & 2,210 & 24,553 & 11.11 & 2,511 & 20,239 & 8.06 & 2,500 & 21,300 & 8.52 & 2,500 & 21,300 & 8.52 \\
\hline Portugal & 1,750 & 11,725 & 6.70 & 1,820 & 10,975 & 6.03 & 2,400 & 12,528 & 5.22 & 2,150 & 10,686 & 4.97 & 2,500 & 12,425 & 4.97 \\
\hline France & 1,250 & 9,525 & 7.62 & 1,000 & 6,860 & 6.86 & 1,400 & 9,492 & 6.78 & 1,700 & 9,588 & 5.64 & 1,500 & 8,775 & 5.85 \\
\hline Cyprus & 828 & 5,564 & 6.72 & 986 & 5,502 & 5.58 & 1,384 & 7,474 & 5.40 & 1,278 & 6,326 & 4.95 & 1,266 & 6,647 & 5.25 \\
\hline Croatia & 650 & 4,641 & 7.14 & 650 & 4,817 & 7.41 & 700 & 6,062 & 8.66 & 900 & 7,668 & 8.52 & 900 & 7,668 & 8.52 \\
\hline Egypt & 651 & 4,036 & 6.20 & 271 & 1,653 & 6.10 & 875 & 5,163 & 5.90 & 915 & 4,941 & 5.40 & 982 & 4,910 & 5.00 \\
\hline Malta & 1,870 & 9,032 & 4.83 & 1,922 & 7,573 & 3.94 & 1,512 & 4,702 & 3.11 & 1,091 & 3,022 & 2.77 & 750 & 2,078 & 2.77 \\
\hline Tunisia & 66 & 483 & 7.32 & 39 & 325 & 8.33 & 409 & 3,542 & 8.66 & 448 & 3,965 & 8.85 & 352 & 3,115 & 8.85 \\
\hline Morocco & 161 & 898 & 5.58 & 466 & 1,981 & 4.25 & 400 & 2.204 & 5.51 & 304 & 1.207 & 3.97 & 300 & 1.191 & 3.97 \\
\hline Total & 62,682 & 362,822 & 5.79 & 65,502 & 327,367 & 5.00 & 80,290 & 384,477 & 4.79 & 91,840 & 371,608 & 4.05 & 101,598 & 413,785 & 4.07 \\
\hline
\end{tabular}

Source: partner reports, FAO if gaps 